\title{
Thankot Active Fault in the Kathmandu Valley, Nepal Himalaya
}

\author{
Katsuhiko Asahi \\ Graduate School of Environmental Earth Science, Hokkaido University, \\ Sapporo, 060-0810 Japan \\ (E-mail: asahi@ees.hokudai.ac.jp)
}

\begin{abstract}
A WNW-ESE trending active fault (ca. $6 \mathrm{~km}$ long) named as Thankot Active Fault (TAF) has been recognized in the south western part of the Kathmandu Valley. The fault with low scarps, flexure, fault trench, minor graben, and sag pond cuts through the terraces and alluvial fans along the foot of the northern flank of the Chandragiri Range. Based on the morphotectonic features and configuration along the fault, the fault has been identified as a reverse fault on the southwestern area but shows normal faulting on the northeast. The vertical rate of displacement along the fault is less than $1 \mathrm{~mm} \mathrm{a}^{-1}$. The Thankot Active Fault runs counter to the Chitlang Fault, another active fault just outside Kathmandu Valley. The sense of these two faults may imply a conjugate system putting the Chandragiri Range between a pair of active faults.
\end{abstract}

\section{INTRODUCTION}

Uplift of the Himalaya, which has been attributed to the collision and northward shift of the Indian sub-continent, produced the four main active fault systems in the Nepal Himalaya. They are: the Main Central Active Fault system, the active faults in the Lesser Himalaya, the Main Boundary Active Fault system, and the active faults along the Himalayan Frontal Fault (Nakata 1982). Active faults developed along with Main Central Thrust (MCT), Main Boundary Fault (MBT) and Himalayan Frontal Fault (HFF) as well as those in the Lesser Himalaya have been the subject of study over the past decades (Kimura 1999). Study of active faults in and around Kathmandu helps to understand the crustal structure of the Kathmandu Basin.

In this study, the precise delineation of the Thankot Active Fault was done using the latest aerial photographs and topographic maps. Also the active fault was verified in field by studying the displacement or deformation of the sediment along the fault trace. Based on these observations, the tectonic setting of the area is discussed.

\section{PREVIOUS STUDY}

Nakata (1982) mapped and described many active faults in Nepal by interpreting the available aerial photographs and carrying out field surveys. He also described active faults around the Kathmandu Valley. The Kalphu Khola Fault which lies outside the valley to the northwest, is about 10 $\mathrm{km}$ long with a WSW-ENE strike. Outside the Kathmandu Valley to the southwest lies the Chitlang Fault which trends along the NW-SE direction and runs for about $7 \mathrm{~km}$. Farther to the south, the Kulikhani Fault extends along a NW-SE direction for $10 \mathrm{~km}$ along the Kulikhani River. To the east of the basin, the Sun Koshi-Rosi fault system is ca. $40 \mathrm{~km}$ long running along NW-SE direction. All these faults are north dipping faults.

Saijo et al. (1995) recognized two active faults around the Chobar Gorge in the southern part of the Kathmandu Valley. The Chobar Fault, located along the northern base of the Kirtipur and Chobar hills, is approximately $3 \mathrm{~km}$ long with a NW-SE strike. Another fault named as Chandragiri Fault is $2 \mathrm{~km}$ long and occurs on the northern foot of the Chandragiri Range. It has the same strike direction as that of the Chobar Fault. Yagi et al. (2000) also mapped active faults inside and outside of the Kathmandu Valley by using aerial photographs. He recognized the Kathmandu South Fault along with several faults described by Nakata (1982). His Kathmandu South Fault begins at Thankot, west end of the Kathmandu Valley, and runs for about $15 \mathrm{~km}$ reaching near Bhaktapur in the east.

In addition to these neotectonic studies, the engineering and environmental geological maps of Kathmandu (Koirala et al. 1993; Shrestha et al. 1998, 1999) shows several faults and/or lineaments inside the valley. However, it is still not clear whether these structures are active faults or simply lineaments. Similarly, Sakai (2001) mapped Danuwargaun Fault in the southern Kathmandu Valley and according to him this fault was responsible for the discharge of water from the Paleo-Kathmandu Lake.

\section{PRESENT INVESTIGATION}

At first, vertical aerial photographs in and around the Kathmandu Valley were interpreted using a stereoscope. Active fault trace was carefully delineated on 1:25000 topographical maps. The interpretation and the determination of the landforms were based on the criteria that the fault scarps have no fragments but clear continuity. 
Then an active fault with ca $6 \mathrm{~km}$ long was able to be detected at the western part of the Kathmandu Valley, termed here the Thankot Active Fault (TAF; Fig. 1). This active fault coincides with the Chandragiri Fault of Saijo et al. (1995) near its eastern end.

Surface rupture of the TAF coincides with the trace of the western part of the Kathmandu South Fault as mapped by Yagi et al. (2000) and its eastern end extends up to Bhaktapur. However, the fault topography in the eastern part of the Kathmandu South Fault mainly consists of flexure, and it shows studded-like continuity. However, no displacement or deformation of sediment was found in the field. The flexures are most likely to be talus deposits, which mantle terrace scarps. Additionally, morphotectonic features are less evident in the eastern part of the Kathmandu South Fault. Similarly, clear tectonic landforms could not be found along the Chobar Fault, which Saijo et al. (1995) have described at the northern base of the Kirtipur and Chobar hills. These all features, therefore, demonstrate that only the TAF has the scarplet that provides proof of the presence of an active fault inside the Kathmandu Basin.

\section{THANKOT ACTIVE FAULT}

The Thankot Active Fault (TAF) extends continuously east-southeastward for about $6 \mathrm{~km}$ from Thankot Town lying at the west end of the Kathmandu Valley, to Machhegaun situated at the right bank of the Bagmati River (Fig. 2). The fault trace occurs along the northern foot of the Chandragiri Range (Fig. 3). The vertical displacement along the fault is up on the southwest and down on the northeast (Fig. 4). Fault and flexure scarps, fault trench, minor graben, and sag pond occur on the terraces and alluvial fans, which were developed during the Last Glacial period (Saijo 1991).

At the west end of the fault, relative height of the northfacing scarplet on the alluvial fan is $2 \mathrm{~m}$ in height (Fig. 4 -A). The fault trace runs along the Tribhuvan Highway, which is located just on the scarplet. Farther to the east, the fault

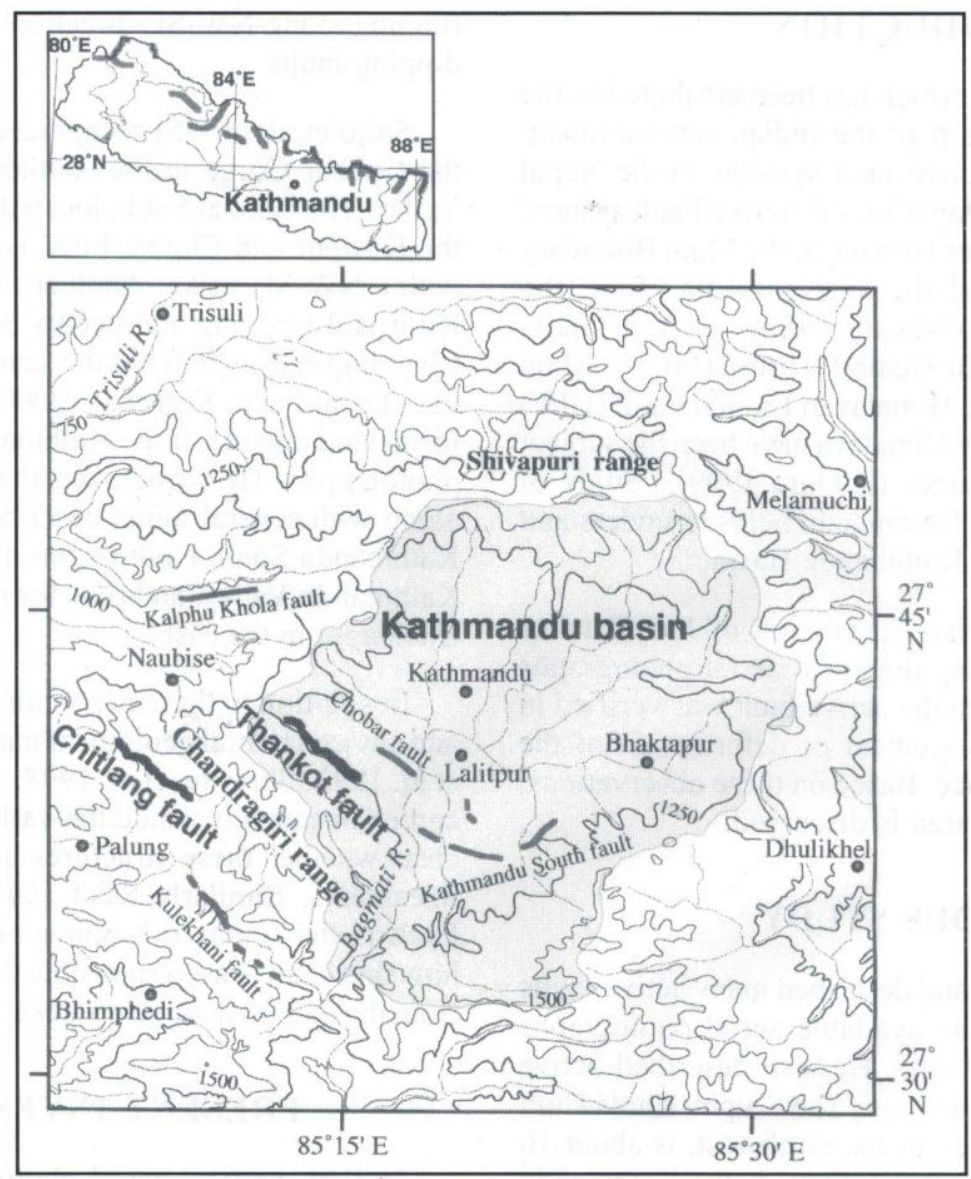

Fig. 1: Topography of the greater Kathmandu Basin. Hatched area represents inside of the Basin. Solid line represents active faults, which delimited by both previous and this studies. KKF, Kalphu Khola Fault (Nakata 1982); KF, Kalekhani Fault (Nakata 1982); CF, Chobhar Fault (Saijo et al. 1995); KSF, Kathmandu South Fault (Yagi et al. 2000). 


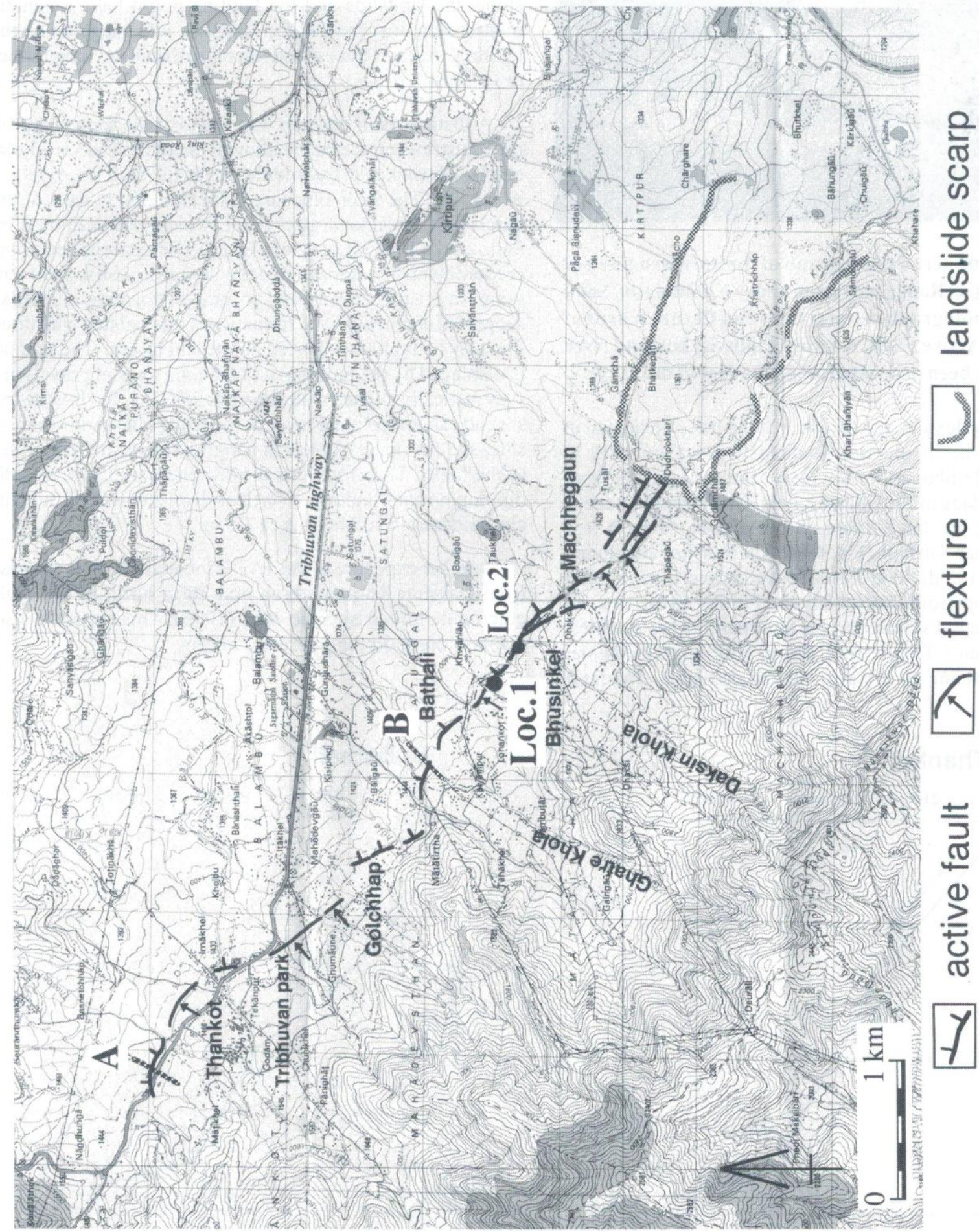




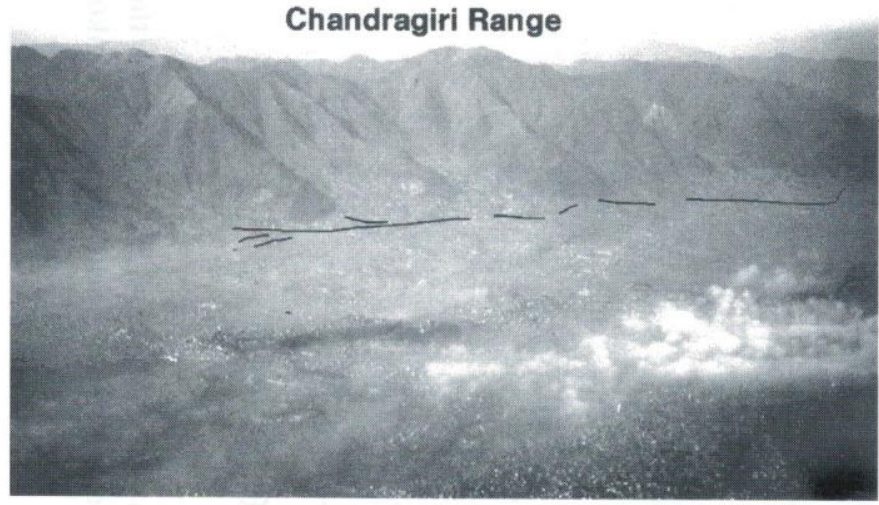

Fig. 3: Oblique aerial photograph of the northern flank of the Chandragiri Range seen from above Kathmandu. Solid line on the photograph denotes fault and flexure scarps of the Thankot Active Fault. A series of alluvial fans and river terraces have been dislocated along the foot of the range.

scarp shifts to flexure, and shows arc-like trace on the fan at Thankot Town. It extends southeastward about $500 \mathrm{~m}$ through the Tribhuvan Park. New segment appears from Golchhap Village to the Ghatre Khola Fan. Here the trace is curved along the fan surface and is dislocated by a low scarplet less than $8 \mathrm{~m}$ high (Fig. 4-B). The fault line continuing southeastward is divided into two traces and they parallel with each other from Daksin Khola. Farther to the east, an alluvial terrace is dislocated by the three parallel low scarplets at Machhegaun. This terrace slump with huge landslide, and the fault segments are also cut and end here. The fault trace is not able to stretch into the portion of the landslide. Surface of the landslide rupture truncates the mountain slope with NW-SE strike, suggesting a similar strike direction as that of the TAF. Because the landslide occurs on a gentle slope, the landslide and the faulting might have a genetic relationship. In case that the landslide was triggered by the faulting, the fault trace could run more than $8 \mathrm{~km}$ long farther to the east.

A distinct fault outcrop was found at the fault scarp on the lacustrine terrace on the alluvial fan of the Daksin Khola, nearby Bhusinkel, at the middle part of the fault trace (Loc. 1 in Fig. 2). The fault exposure is located $300 \mathrm{~m}$ west of the outcrop of the Chandragiri Fault, which was delimited by Saijo et al. (1995) (Loc. 2 of Fig. 2). The exposed section is predominantly composed of delta deposits, whose sediment grain size varies from sand to gravel, forming a matrixsupported diamictite. The formation is intercalated with three thin clay beds and two buried humic soil layers. The section is displaced by the faulting, and the long axes of gravels are systematically aligned with slip direction (Fig. 5). Interbeded silt and clay show titling towards the fault plane in downthrow side, and the upper gravels in hanging side also dip parallel to the fault. Therefore, this displacement indicates a north dipping normal faulting. Vertical displacement of the silt, clay and buried soil beds is ca $3.5 \mathrm{~m}$.

Another exposure of the TAF is located $300 \mathrm{~m}$ to the east from Dakshin Khola outcrop and $20 \mathrm{~m}$ north of the fault outcrop delimited by Saijo et al. (1995). This exposure also displays north dipping normal faulting.
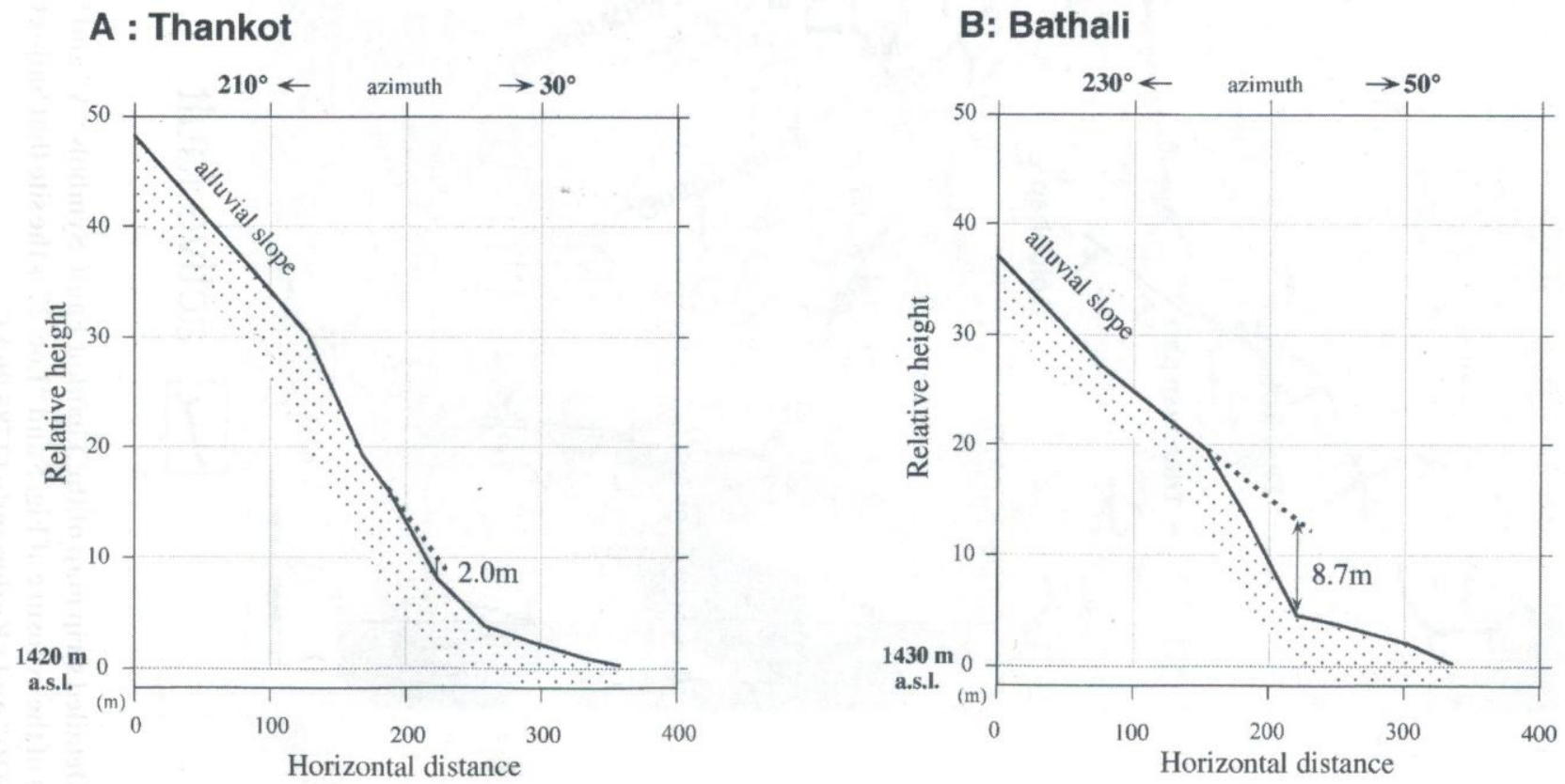

Fig. 4: Transverse section across the Thankot Active Fault based on ground survey. Locality is shown in Fig. 2. 


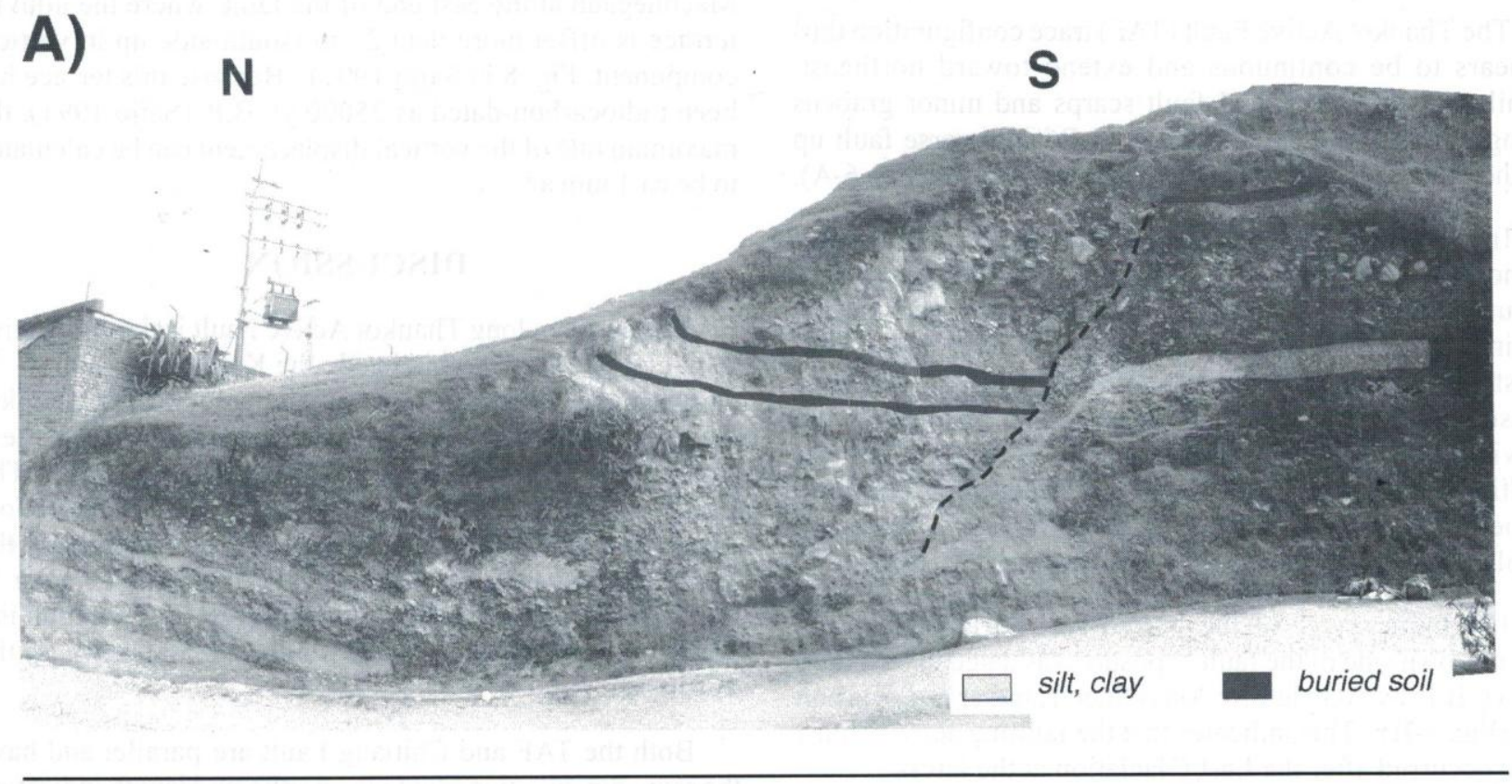

B)

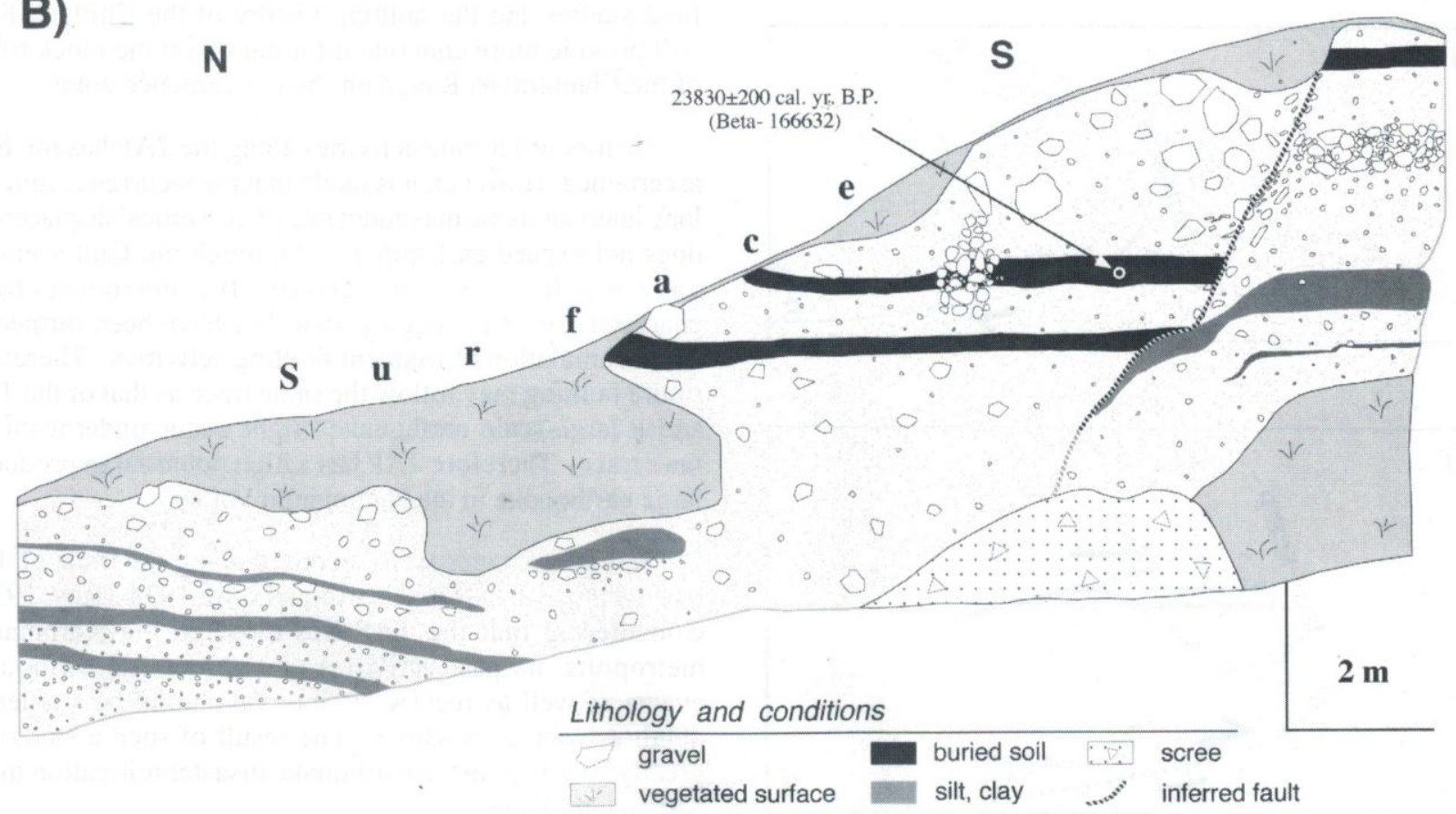

Fig. 5: Fault exposure at Bhusinkhel (Loc. 1 in Fig. 2). The fault appears on the west-facing wall.

(A) Photograph of the exposure. Broken line on the figure denotes fault plane. (Photo by R. Takashima)

(B) Sketch of the exposure. The beds consist of silt and clay, and show tilting in downthrow side (to the left). Long axes of gravel systematically aligned with dip direction. The sediment mainly consists of delta deposits of the Paleo-Kathmandu Lake, and belongs to the Gakarna Formation, which has been described in detail by Sakai et al. (2001). Accelerator Mass Spectrometer radiocarbon age (beta-166632) of 23830 cal.yr.B.P. has been obtained from the upper buried soil layer in the downthrow side. 


\section{FAULT ACTIVITY}

The Thankot Active Fault (TAF) trace configuration thus appears to be continuous and extend toward northeast. Similarly, well-developed fault scarps and minor grabens along the trace indicates that the TAF is a reverse fault up on the southwest and normal fault on the northeast (Fig. 6-A).

In contrast, the TAF exposure nearby Bhusinkel demonstrates normal faulting (Fig. 5). The trace of the fault occurs along the foot of the Chandragiri Range. In this setting, because a hanging block thrusts over a footwall, crustal shortening can occur. This shortening my have caused instability along the fault scarp prompting the gravitational faulting or collapse. This is why the normal faulting has occurred at the outcrop of Bhusinkel. This fault plane is not the master fault of the TAF, but a secondary displacement triggered by the main faulting (Fig. 6-B).

The upper layer of the buried soil horizon from the downthrown side of the fault exposure was dated to be 23830 cal. yr. B.P. by Accelerator Mass Spectrometer radiocarbon age (Fig. 5-B). This indicates that the faulting activity must have occurred after the Last Glaciation at the latest.
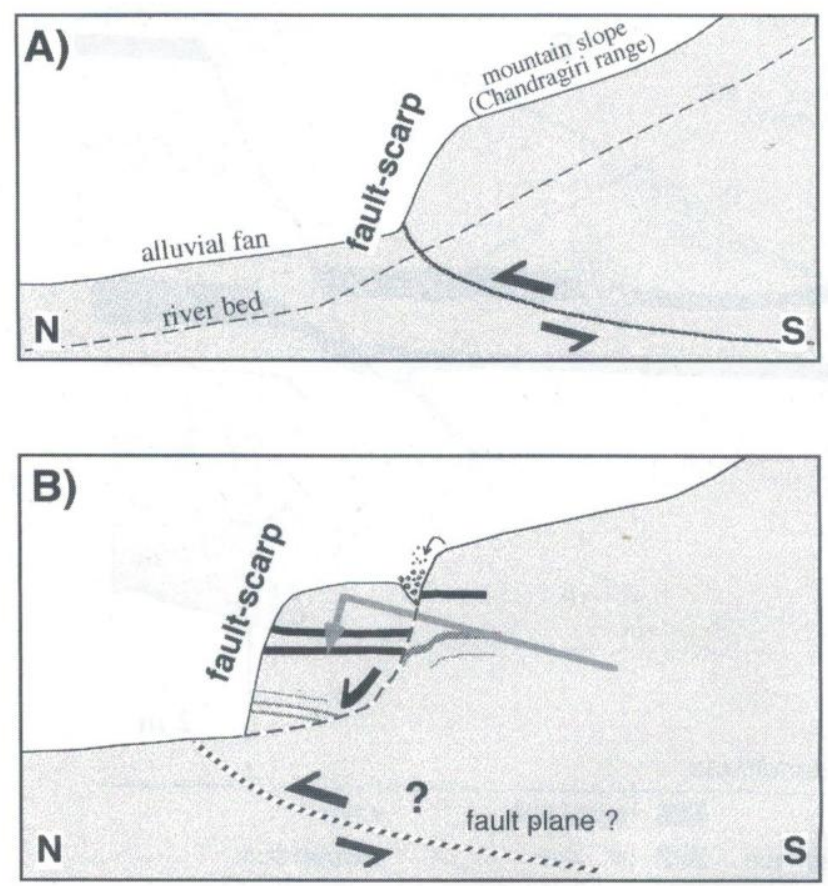

Fig. 6: Schematic diagram showing the displacement on the Thankot Active Fault.

A: Faulting activity (reverse faulting) is inferred by morphocharacteristic features of the fault trace. The slope of the Chandragiri range overrides the alluvial fan.

B: The fault exposure at Bhusinkhel showing the instability along the fault scarp triggering gravitational collapse. The position of the fault plane is inferred.
The maximum vertical displacement is observed near Machhegaun at the east end of the fault, where the alluvial terrace is offset more than $25 \mathrm{~m}$ (south-side up in vertical component, Fig. 8 in Saijo 1991). Because this terrace has been radiocarbon-dated as $25000 \mathrm{yr}$. B.P. (Saijo 1991), the maximum rate of the vertical displacement can be calculated to be ca. $1 \mathrm{~mm} \mathrm{a}^{-1}$.

\section{DISCUSSION}

The ca. $6 \mathrm{~km}$ long Thankot Active Fault is the only active fault clearly recognizable inside the Kathmandu Valley. In addition, the Chitlang Fault runs counter to the Thankot Fault putting the Chandragiri Range between a pair of these active faults (Fig. 1: Nakata 1982; Yagi et al. 2000). The Chitlang Fault stretches ca. $6 \mathrm{~km}$ along WNW-ESE direction, which has almost the same strike direction as that of the TAF. Distinct fault saddles and reverse scarplets occur in the slope along the straight fault trace (Fig. 7). The fault is a normal dip-slip fault up on the southwest and down on the northeast.

Both the TAF and Chitlang Fault are parallel and have the same dip direction (dip to the north), and length indicating that they represent a conjugate fault system (Fig. 8). Further field studies and the faulting history of the Chitlang Fault will provide more concrete information on the block tilting of the Chandragiri Range on the convergence zone.

History of faulting activities along the TAF has not been ascertained. However, it is likely that the recurrence time has long intervals as the maximum rate of the vertical displacement does not exceed ca. $1 \mathrm{~mm} \mathrm{a}^{-1}$. Although the fault seems to have a relatively low activity, the morphotectonic characteristics still suggests that they have been formed by the accumulation of frequent faulting activities. Therefore, future faulting may follow the same trace as that of the TAF, and a large-scale earthquake might occur underneath the fault trace. Therefore TAF has a high potential to produce a large earthquake in the Kathmandu Valley.

Serious damages were recorded along the trace of TAF during the Bihar-Nepal earthquake of 1934 (Roy 1939). Considering that the TAF lies close to the Kathmandu metropolis, its past activities and associated earthquake events as well as recurrence interval should be studied in detail as soon as possible. The result of such a study can greatly help to plan the earthquake disaster mitigation in the Kathmandu Valley.

\section{CONCLUSIONS}

1. The Thankot Active Fault (TAF) is the only active fault so far recognizable in the Kathmandu Valley. It is ca $6 \mathrm{~km}$ long and strikes along WNW-ESE direction and dips to northeast at the western part of the Valley.

2. Morphotectonic features of the fault show that the TAF is a north dipping reverse fault, and that its vertical rate of displacement is less than $1 \mathrm{~mm} \mathrm{a}^{-1}$. 


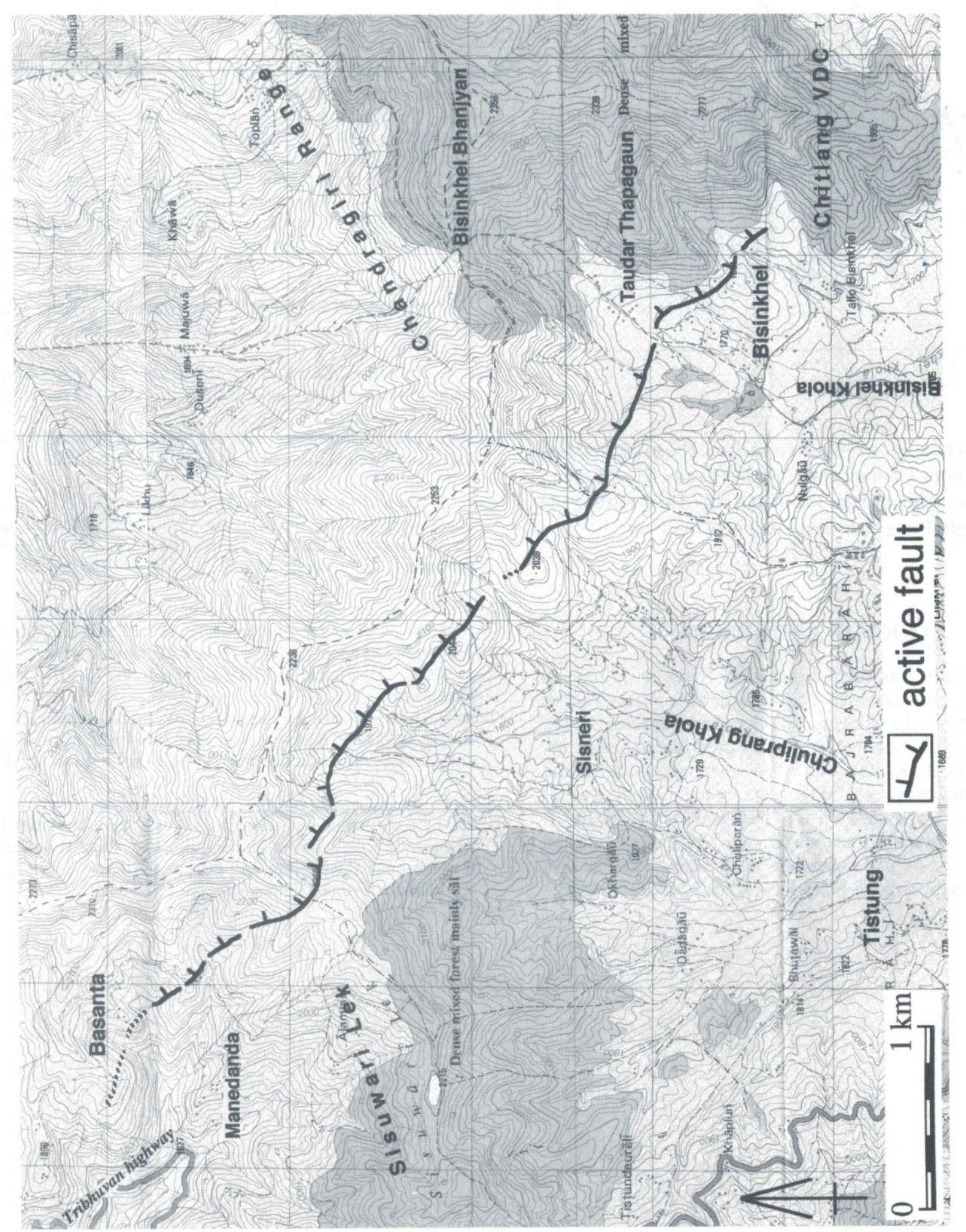




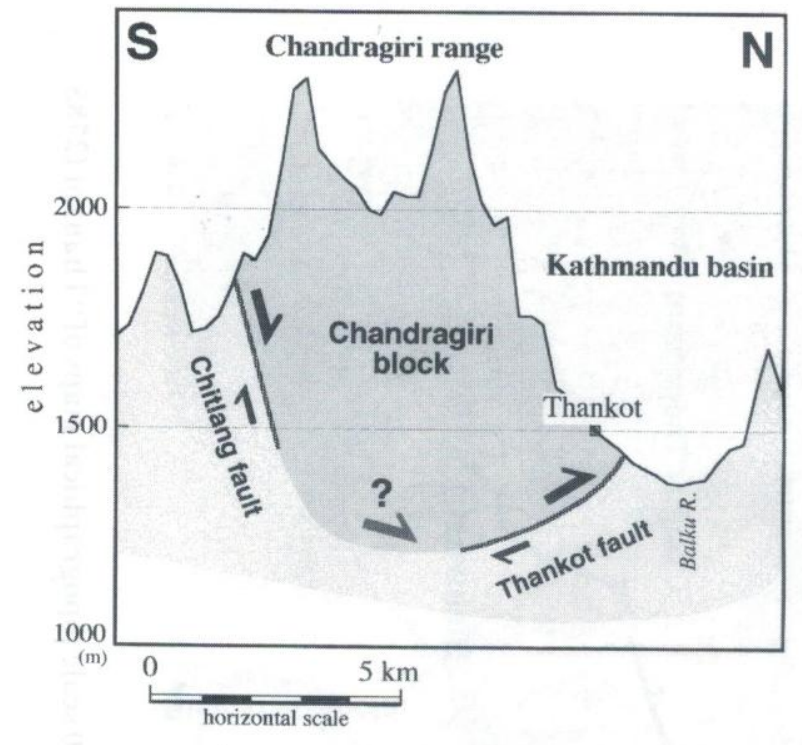

Fig. 8: Schematic transverse section showing faulting activities both Thankot and Chitlang Faults. The Chitlang Fault runs counter to the Thankot Active Fault putting the Chandragiri Range between a pair of active faults.

\section{ACKNOWLEDGEMENTS}

This study was carried out when I was in Tribhuvan University as a Research Fellow under the Asian Studies Program from the Ministry of Education, Culture, Sports, Science and Technology, Japan. I would like to extend my gratitude to Dr. K. Kimura for his constructive advice and Dr. Y. Kumahara for useful suggestions at the initial phase of this study. Comments on the draft manuscript by Dr. T. Watanabe is gratefully acknowledged. Drs. T: Tanokura and R. Takashima helped during the field work. The research was partly supported by Grant-in-Aid for Scientific Research from the Japan Society for the Promotion of Science (No.14000268 to the author; No.11304030 to H. Sakai; 11691112 to K. Arita).

\section{REFERENCES}

Kimura, K., 1999, Diachronous evolution of sub-Himalayan piggyback basins, Nepal. The Island Arc, v. 8, pp. 99-113.

Koirala, A., Shrestha, O. M., and Karmacharya, R., 1993, Engineering geology of the southern part of Kathmandu Valley. Bull. Dept. Geol. Tribhuvan Univ., v. 3, pp. 151-159.

Nakata, T., 1982, A photogrametric study on active faults in the Nepal Himalayas. Jour. Nepal Geol. Soc., v. 2, pp. 67-80.

Roy, S. C., 1939, The Bihar-Nepal earthquake of 1934 by officers of the geological survey of India. Mem. Geol. Sur. India, v. 73 , $454 \mathrm{p}$.

Saijo, K., 1991, Slope evolution since latest Pleistocene time on the north slope of Chandragiri, Kathmandu valley in the middle mountains of Nepal. Sci. Rep. Tohoku Univ. Ser. 7, v. 41 , pp. 23-40.

Saijo, K., Kimura, K., Komatsubara, T., and Yagi, H., 1995, Active faults in southwestern Kathmandu basin, central Nepal. Jour Nepal. Geol. Soc., v. 11, pp. 217-224.

Sakai, H., 2001, Danuwargaun fault as a trigger for draining of the Palaeo-Kathmandu Lake, central Nepal. Jour. Nepal Geol. Soc., v. 25 , pp. $89-92$.

Sakai, T., Gajurel, A. P., Tabata, H., and Upreti, B. N., 2001, Small-amplitude lake-level fluctuations recorded in aggrading deltaic deposits of the upper Pleistocene Thimi and Gokarna formations, Kathmandu valley, Nepal. Jour. Nepal Geol. Soc., v. 25 , pp. $43-51$.

Shrestha, O. M., Koirala, A., Karmacharya, S. L., Pradhananga, U. B., Pradhan, R., and Karmacharya, R., 1998, Engineering and environmental geological map of the Kathmandu valley, scale 1: 50000. Department of Mines and Geology, HMG/Nepal, Kathmandu.

Shrestha, O. M., Koirala, A., Hanisch, J., Busch, K., Kerntke, M., and Jäger, S., 1999, A geo-environmental map for the sustainable development of the Kathmandu Valley, Nepal. Geo. Journal, v. 49 , pp. $165-172$.

Yagi, H., Maemoku, H., Ohtsuki, Y., Saijo, K., and Nakata, T., 2000 , Recent activities of active faults distributed in and around Kathmandu valley, Lower Himalayan Zone. Proc. Hokudan international symposium and school on active faulting. Hiroshima University, Hiroshima, pp. 557-560. 